This is a self-archived version of an original article. This version may differ from the original in pagination and typographic details.

Author(s): Särkkä, Timo

Title: The Lure of Katanga Copper : Tanganyika Concessions Limited and the Anatomy of Mining and Mine Exploration 1899-1906

Year: 2016

Version: Accepted version (Final draft)

Copyright: @ UNISA Press; Taylor \& Francis, 2016

Rights: In Copyright

Rights url: http://rightsstatements.org/page/InC/1.0/?language=en

Please cite the original version:

Särkkä, T. (2016). The Lure of Katanga Copper : Tanganyika Concessions Limited and the Anatomy of Mining and Mine Exploration 1899-1906. South African Historical Journal, 68(3), 318-341. https://doi.org/10.1080/02582473.2016.1153707 
The lure of Katanga copper: Tanganyika Concessions Limited and the anatomy of mining and mine exploration 1899-1906

Timo Särkkä

Academy of Finland Postdoctoral Researcher

University of Jyvaskyla

Department of History and Ethnology

P.O. Box 35

FI-40014 University of Jyvaskyla

Finland

Email. timo.sarkka@jyu.fi

Tel. +358408093958 


\title{
The lure of Katanga copper: Tanganyika Concessions Limited and the anatomy of mining and mine exploration 1899-1906
}

\begin{abstract}
This article provides a rare opportunity to follow the inception of mining and mine exploration economy in the first years of the European presence in colonial Zambia and Katanga as seen through the eyes of prospectors and mining experts working for the London-based company Tanganyika Concessions Limited. It draws on company records as well as the personal records of the early company employees who worked in North Western Rhodesia and adjoining Katanga until 1906. The most thought-provoking documents include diaries, letters and photographs, which depict the organisation and processes of early mining work, modes of mine exploration, and relations within the first mining communities and between white management and African labour. The wide range of available materials makes the Tanganyika Concessions a relevant case study; they offer a fuller picture of the inception of European mining and mine exploration in North Western Rhodesia and Katanga than is available elsewhere. Taken as a whole, they provide insight into the operation of colonising processes: in particular how these processes took place, why they were considered desirable by various interest groups, and the impact that these processes had on physical and human environments in parts of North Western Rhodesia and Katanga.
\end{abstract}

\section{Keywords}

Mining, mine exploration, copper, Northern Rhodesia, Katanga, photography 


\section{Introduction}

Although mining in colonial Zambia and Katanga has been analysed both by economic historians and by researchers of colonialism, very little is known of individual mining companies' operations on the ground before 1914. This article concentrates on the inception of mining and mine exploration economy of Tanganyika Concessions Limited (hereafter Tanks) from 1899 to 1906. The first successful effort to set up a mining industry in the mineral-rich region that later became popularly and loosely known as the Copperbelt was undertaken by Tanks, which was listed on the London Stock Exchange on 20 January $1899 .^{1}$

The impetus and much of the capital for the exploitation of copper in Northern Rhodesia and Katanga originated from British mining interests that had been operating in Southern Africa since the late 1860s. The discovery of diamonds in the country to the west of Bloemfontein (later known as the Kimberley diamond fields) in 1866 had drastically altered South Africa's significance as a source of mineral wealth. By the 1870s the Kimberley diamond fields had already been transformed from an area of small claims into one run by joint stock companies. In 1888 Cecil Rhodes brought the Kimberley diamond mines under the control of De Beers Consolidated Mines Limited, one of the largest business organisations of the period. British investments in colonial Southern Africa were by nature such that, despite formal ties through limited liability companies, they were often if not always based on the trust of close friends and shared financial assets. ${ }^{2}$

\footnotetext{
${ }^{1}$ Copper is not mentioned in Tanks' prospectus issued on 25 February 1899. Initial hopes were pinned on 'the existence of ancient gold workings' and 'the presence of alluvial gold'. (Guildhall Library, Records of the Stock Exchange, London, Company Prospectuses, Tanganyika Concessions Limited, 6).

${ }^{2}$ C. Newbury, 'Rhodes, De Beers and the Mining Finance in South Africa: The Business Entrepreneurship and Imperialism', in R.E. Dumett, ed, Mining Tycoons in the Age of Empire,
} 
In his analysis of these vested interests in the South African mining industry, J.A. Hobson, the famed theorist of imperialism, saw investors and financiers as the true beneficiaries of economic imperialism. The growth of the 'new imperialism' from the 1870s had coincided with a remarkable growth in the income derived from the external investments. Hobson argued that imperialism was 'a source of great gains to the investor who cannot find at home the profitable use he seeks for his capital and insists that his Government shall help him to profitable and secure investments abroad. ${ }^{3}$ Cui bono? Who benefits? Hobson's answer ran thus: the investor.

A succession of economic historians have analysed Hobson's theory in detail and studied the role of the metropolitan economy in overseas expansion. 'Gentlemanly capitalism' has been defined as a process in which industrial interests were shunned as socially inferior to the more lucrative and prestigious business of exporting capital. ${ }^{4}$ Researchers of colonialism have been critical of what they term 'monocausal' economic explanations of imperialism, and Hobson's

1870-1945: Entrepreneurship, High Finance, Politics and Territorial Expansion (Farnham: Ashgate, 2009), 87.

3 J.A. Hobson, 'Imperialism. The Policy of Investors', The Speaker, V, 112 (November 23 1901), $210-211$.

${ }^{4}$ P.J. Cain and A.G. Hopkins, British Imperialism, 1688-2000 (London: Longman, 2002), 337-338. Unlike Hobson, however, they did not believe that the South African War was fought at the behest of the investors and financiers but because Britain was an advancing power whose interests collided with that of the Boers (loc. cit.). For earlier versions, see idem, 'The Political Economy of British Expansions Overseas, 1750-1914', Economic History Review, 33, 4 (November 1980), 463-490; idem, 'Gentlemanly Capitalism and British Expansion Overseas II: New Imperialism, 1850-1945', Economic History Review, New Series, 40, 1, (February 1987), 1-26. 
theory in particular. ${ }^{5}$ In South African historiography a belief in economic determinism in historical writing that emerged in the interwar period in the form of the so-called "Hobson-Lenin theory" tended to overemphasise the role of the capitalist at the expense of the worker and the peasant in making their own history. ${ }^{6}$ However, the broad point that British capital ultimately revolutionised economies and societies throughout Southern Africa has remained undisputed.

In the Transvaal (where the British share of total investments was estimated to be 70 per cent), the mining industry was dependent on the City for investments, loans and other financial services. In the newly occupied territories in Rhodesia the relationship between economic imperialism and territorial expansion was not so evident. ${ }^{7}$ However, even in Rhodesia, the nature of colonial business ventures is difficult to appreciate without company-level studies of capital accumulation. $^{8}$

Existing research has shown that analysis of London-based mining companies can contribute to our understanding of the ambiguous relationship between the interests of the Empire and those of the City. ${ }^{9}$ In previous research on Tanks the focus has been on the business activities of

${ }^{5}$ D. Cannadine, History in Our Time (New Haven and London: Yale University Press, 1998), 144$146,150-154$.

${ }^{6}$ On this concern see in particular I. Phimister, An Economic and Social History of Zimbabwe 1890-1948: Capital Accumulation and Class Struggle (London and New York: Longman, 1988).

${ }^{7}$ I. Phimister, 'Empire, Imperialism and Partition of Africa' in Shigeru Akita, ed, Gentlemanly Capitalism, Imperialism, and Global History (Houndmills, Basingstoke: Palgrave Macmillan, 2002), 74, 79 .

${ }^{8}$ I. Phimister, 'Speculation and Exploitation: The Southern Rhodesian Mining Industry in the Company Era', Historia, 48, 2 (November 2003), 88-97.

${ }^{9}$ For Ian Phimister such material has enabled a 'better understanding of the peculiar nature of British overseas expansion and imperialism' and highlights the point that 'the concerns of the City, 
the company's management, the London headquarters operations and the connections between finance and high politics in Britain and Belgium. ${ }^{10}$ The present article's contention is different from previous approaches in three respects. First, it shifts the focus from the company headquarters to the host countries, on the ground, where operations were run by local management with the help of engineering firms, suppliers and service sector agencies. Second, instead of the company's management, the manager, the directors or the major shareholders (investors), this article focuses on the 'pioneers', who have conventionally been considered 'far too busy making history to find time to write it'. ${ }^{11}$ Finally, this article is concerned with a shorter time-frame and focuses specifically on the less frequently examined period of exploration and experimental mining and smelting (from 1899 to 1906$).^{12}$

where these approximated informal imperialism, were not always the same as the interests of formal empire.' See I. Phimister, 'Corners and Company-Mongering: Nigerian Tin and the City of London, 1909-12', The Journal of Imperial and Commonwealth History, 28, 2 (2000), 38. Similar conclusions were reached by some of the early critics of imperialism, most notably by J.A. Hobson in the context of South African finance. J.A. Hobson, 'The Structure of South African Finance', The Speaker, XII, 291 (April 29 1905), 117-118.

${ }^{10}$ See especially S.E. Katzenellenbogen, Railways and the Copper Mines of Katanga (Oxford: Clarendon Press, 1973); R. Hutchinson and G. Martelli, Robert's People: The Life of Sir Robert Williams Bart. 1860-1938 (London: Chatto \& Windus, 1971).

${ }^{11}$ W.V. Brelsford, 'Editorial', The Northern Rhodesia Journal, I (1950-1952), 6.

${ }^{12}$ Studies focusing on mining business on the Copperbelt have tended to start their analysis from 1906 or after 1914 (the era of production on a commercial scale). See, for instance, Union Minière du Haut Katanga 1906-1956 (Bruxelles: L. Cuypers, 1956). 
A study of a London-based mining and mine exploration company should not, however, necessarily be concerned with economic activity alone. ${ }^{13}$ British involvement in mining in Southern Africa ultimately stemmed from colonial developments. Tanks was also a direct participant in the colonising process, and its activities had physical and societal consequences in parts of North Western Rhodesia and Katanga, including the establishment of the first mining camps and the inception of the wage labour system. Business history resources together with various written and visual materials produced by many company employees can provide some insight into how these processes took place, why they were considered desirable by various interest groups, and what implications such processes had for both physical and human environments.

In order to analyse, discuss and answer these concerns, this article draws on personal records (diaries and travelogues) of some of Tanks' first European employees in Northern Rhodesia and Katanga. The labels 'white' and 'European' are commonly used in conjunction with 'employee' as blanket terms to emphasise the stark contrasts between white management and black labour. The difficulty is that the use of generic terms such as 'white' or 'European' tends to obscure the extent of ethnic and national diversity on the ground. From its very inception, the South African mining industry attracted a motley of nationalities and ethnicities from diverse social and professional backgrounds. Tanks' early mining communities were highly cosmopolitan in nature: white workers would be defined as being 'German-born', 'Finnish-born', 'Transvaaler', and 'Portuguese', for

\footnotetext{
${ }^{13}$ The economic history of Tanks can be traced with some accuracy from its company records. Manchester University (hereafter MU), John Rylands Library (hereafter JRL), Tanks Group Archive (hereafter TANKS).
} 
example. As a consequence, some of the sources consulted in this article have been written in languages that have as yet rarely been heard in accounts of the colonial experience. ${ }^{14}$

Besides written records produced by white employees, the question of Tanks' impact on physical and human environments is approached through photography. ${ }^{15}$ The selected pictures depict various aspects of the early colonial economy, including the organisation and processes of the early mining work, modes of communication and relations between Tanks' white employees and the local population. The actual manual mining work undertaken by African labourers - such as the sinking of shafts and extraction of ore using only axes, picks, shovels and wheelbarrows - can hardly be appreciated without illustrations. Given our purpose of viewing depictions of scenes and people otherwise known to us only through the written word, it is nevertheless important to remember that the photographs can also provide a means by which to analyse theoretical and

${ }^{14}$ Here, this concern is approached from a practical (i.e. neglected sources in scholarly research dealing with Tanks) rather than a methodological (e.g. emphasis on national identities within early settler societies) point of view.

15 The photographs in question come from Carl Theodor Eriksson's picture collections. Eriksson was a Finnish-born Tanks employee, whose life and times in colonial Southern Africa is exceptionally well documented thanks to his surviving diaries and photographs. His collection of photographs includes numerous original glass plate negatives taken during the five years of his employment with Tanks in North Western Rhodesia and Katanga (between April 1901 and 31 May 1906). Finland's National Board of Antiquities (hereafter NBA), Picture Collections (hereafter PC), VKK871. Some photographs from this collection have previously been reproduced in older Rhodesiana. However, none of this older material includes a photographer's credit, let alone a critical discussion of Eriksson's photography. 
conceptual definitions of the categories "coloniser" and "colonised" and to discuss their complex interplay. $^{16}$

\section{Tanganyika Concessions Limited: a 'brass nameplate' company in the "Square Mile"}

Prior to 1880 British capital for mining ventures had been for the most part devoted to mining within the British Isles, but the following three decades saw significant expansion overseas. Between 1880 and 1913, 8,408 companies involved in mining and mine exploration overseas were registered in Britain. ${ }^{17}$ These companies were subject to British law, operated under British management and control, and traded on British markets with securities denominated in pounds

16 The camera, "a triumph of Western technology" played many roles in early colonial societies. Colonial photography has been analysed from the perspective of early photographers (imperial othering, intrusive colonial gazing as well as capturing and rearranging colonial subjects) and, conversely, the ways in which colonial subjects were able to use photography for their own ends (through poses and other choices relating to self-representation). On these many roles of colonial photography see, for example, E. Edwards, ed., Anthropology and Photography 1860-1920 (New Haven and London: Yale University Press, 1992); T. Ranger, 'Colonialism, Consciousness and the Camera', Past and Present, 171, 1 (2001), 203-215.

${ }^{17}$ J.-J. Van Helten, 'Mining, Share Manias and Speculation: British Investment in Overseas Mining', in J.-J. Van Helten and Y. Cassis, eds, Capitalism in a Mature Economy: Financial Institutions, Capital Exports and British Industry, 1870-1939 (Aldershot: Edward Elgar, 1990), $161-163$. 
sterling. ${ }^{18}$ A typical pre-1914 company floated for mining and mine exploration overseas was shortlived, speculative in nature, and played a purely economic role in the development of its host country or countries. Even though most mining and mine exploration companies failed, they were not organisationally unsound per se. Rather limited companies were investment instruments, the floating of which was 'an easy matter, and a useful way of investigating a prospect without risking too much capital. Companies were formed and liquidated by collaborating groups of firms and individuals in the normal course of business.' The City of London, with its 'propensity to create companies', was the focus of most of this activity. ${ }^{19}$

The usual business formula adopted by a London-based firm engaged in overseas mining and mine exploration was to court investment, primarily from British individuals but also from foreign investors in London and elsewhere. Companies would seek to attract the attention of investors by circulating a favourable report from a mining expert. After this initial establishment period, it was usual for technical and production matters to be left in the hands of managers who ran operations in the host countries with the help of engineering firms, suppliers and service sector agencies. The board exercised complete financial control with the support of the corporate secretary and the financial and marketing services provided by commercial and financial City firms. Beyond

\footnotetext{
${ }^{18}$ Prior to 1880 , limited companies were registered in Britain under the first Act of 1856, Act of 1862 and four amendments of it. From 1880 onwards several changes were made in legislation in the presumed interest of the investing public. However, Victorian legal requirements governing managerial behaviour were among the most liberal in Western Europe, and the directors remained in complete control of company assets. See Van Helten, 'Mining, Share Manias and Speculation', $165-166$.

${ }^{19}$ C. Harvey and J. Press, 'The City of London and International Trade, 1850-1914', in R.C. Michie, ed., The Development of London as a Financial Centre, Vol. 2: 1850-1914, (London: I. B. Tauris, 2000), 102.
} 
their small staff and seemingly limited managerial resources, these companies were essentially 'free-standing' in the sense that they had little but the 'brass nameplate' of their headquarters in the "Square Mile". ${ }^{20}$

Although companies were nominally free-standing, they were in fact under the management of powerful capitalists. ${ }^{21}$ Tanks was part of a financial combination formed around the managing director, Scottish-born Robert Williams (1860-1930), a major financier of exploration and mining in South-Central Africa. Williams floated the company with the intention of securing a mining concession, which the British South Africa Company (hereafter BSAC), after considerable negotiations, had granted on 26 May 1898. ${ }^{22}$ The Concession covered an area of over 2,000 square

${ }^{20}$ C. Harvey and J. Press, 'Overseas Investments and the Professional Advance of the British Metal Engineers, 1851-1914', The Economic History Review, 42, 1 (1989), 67, 69; Van Helten, 'Mining, Share Manias and Speculation', 165-166; quotations from M. Wilkins, 'The Free-Standing Company, 1870-1914: An Important Type of British Foreign Direct Investment', The Economic History Review, 41, 2 (1988), 264. Tanks' premises were at 30 and 31 Clements Lane, off Lombard Street.

${ }^{21}$ Harvey and Press, 'The City of London and International Trade', 102; Shares were predominantly traded on the London market where companies could 'tap the speculative instincts and savings of the burgeoning middle classes of the south-east and draw on the extended social web of investment that linked the City with traditional landed society'. Van Helten, 'Mining, Share Manias and Speculation', 165-166.

${ }^{22}$ Exploration companies were very active in winning concessions over mineral-bearing land, particularly in the 1890 s, when a large proportion of all new international mining companies were created for purposes of exploration and company promotion. See Harvey and Press, 'The City of London and International Trade', 95. 
miles and gave exclusive surface rights for prospecting and locating 1,000 claims from the BSAC territories north of the Zambesi River. ${ }^{23}$

Tanks shares were allocated in a way that Zambesia Exploring Company Limited (hereafter ZE), acquired a majority of the shares, and in effect the two companies had a double board of directors. ${ }^{24}$ George Grey (1868-1911), younger brother of Sir Edward Grey, British secretary of state for foreign affairs, 1905-1916, was appointed to take charge of Tanks' mine exploration and mining operations on the ground in Africa. ${ }^{25}$ In 1899 there was little indication that Tanks would

${ }^{23}$ MU, JRL, TANKS, Zambesia Exploring Company (hereafter ZE), 4, Herbert Canning for BSAC to Robert Williams, 26 May 1898. Later the agreement was amended in such a way that allowed the location of any part of the 1,000 claims outside the original 2,000 square miles, if necessary. MU, JRL, TANKS, ZE, 4, Robert Williams to ZE, 29 November 1898.

${ }^{24}$ Williams' first company, ZE had been floated on 26 March 1891 with the intention of financing an expedition to Mashonaland, the purpose of which was to verify the area's mineral wealth and to ascertain whether this could justify the extension of the railway from the south. Upon the company's registration Williams became African manager, his brother Oliver London manager and George Cawston, a London barrister-at-law and stockbroker, the first chairman of the board. MU, JRL, TANKS, ZE, Board Minutes, 31 March 1891. Later Tyndale White, a wealthy London businessman and a major shareholder of both ZE and Tanks, took over the chair. MU, JRL, TANKS, ZE, Minute Book 6, 20 January, 1903.

${ }^{25}$ Williams had first met Grey in Mashonaland in 1891. Since that time Grey had acted in the service of Williams' many Bulawayo-based companies. Before becoming African manager for Tanks, Grey had been the first chairman of Williams' Consolidated Buildings, Limited. MU, JRL, TANKS, ZE, 4, Williams’ Consolidated Buildings, Limited, Bulawayo, 7 May 1898. 
eventually become the great South-Central African mining and railway finance company with capital of nearly $£ 10,000,000 .^{26}$

In its early years, the company was hampered both by a lack of capital and by its obligations to the BSAC. ${ }^{27}$ The Chartered Company's interest in its claims was 30 per cent, ${ }^{28}$ its usual royalty claim for mining. ${ }^{29}$ With a vast concession to be worked, Tanks of the early 1900 s was a company with huge expenses but little turnover. Before mines could be put into operation, companies first needed to arrange organised expeditions to search, prospect and peg copper mines, and then to finance the construction of railways from the ports. In the case of Tanks these developments took place, to varying degrees, during its first fifteen years, with the initial mine exploration work being carried out between 1899 and 1902.

${ }^{26}$ Tanks was floated with authorised capital of only $£ 100,000$, but after its registration the company's capital grew rapidly. Hutchinson and Martelli, Robert's People, 100-101. ${ }^{27}$ MU, JRL, TANKS, ZE, 4, George Grey to BSAC, 28 March, 1900. See also L.H. Gann, The Birth of a Plural Society: The Development of Northern Rhodesia under the British South Africa Company, 1894-1914 (Manchester: Manchester University Press, 1958), 118-119.

${ }^{28}$ MU, TANKS, ZE, 3, Sir Robert Williams and Co, 1901-1925, Robert Williams to George Stewart, 24 May 1900.

${ }^{29}$ BSAC, June 26 1906,The Livingstone Mail, II (December 1906). 


\section{Grey’s first expedition: mineral-seeking and empire-building}

[...] travelling through the bush [...] carrying his life in his hands from day to day, sleeping under the open sky at night. Surely this type of man is the true empire-builder. ${ }^{30}$

There are two broadly defined explanations for investments in high risk exploratory projects in colonial Africa. ${ }^{31}$ Initially, a combination of hopes and imprecise information, promoted by popularised myths of exotic lands and easy riches, contributed to expectations of bonanza profits, first from gold extraction ${ }^{32}$ but soon from non-ferrous metals such as tin and copper as well. Straightforward market dynamics began to drive metal exploration and mining development from roughly the turn-of-the-century onwards. ${ }^{33}$ Increased demand for new sources of non-ferrous metals was fuelled by the rising tempo of industrialisation in Europe, North America and Japan. In the era of electricity, copper proved to be the most practical and the most economic medium, whether in the form of bar, rod or wire. Schemes for the transmission of power over ever-greater distances led to enormous increases in the production of wire and cable, which in turn increased demand for sources of minerals. ${ }^{34}$

\footnotetext{
${ }^{30}$ J.N. Justice, 'Prospecting in Northern Rhodesia', Travel, VII, 75 (July 1902), 102.

${ }^{31}$ Taken together they highlight 'the difficulty of coupling theories of mineral discovery to patterns of mining development.' See Phimister, 'Corners and Company-Mongering', 38.

${ }^{32}$ S.M. Mollan, 'Business Failure, Capital Investment and Information: Mining Companies in Anglo-Egyptian Sudan, 1900-13', The Journal of Imperial and Commonwealth History, 37, 2 (2009), 230-232, 234, 243.

${ }^{33}$ Estimations of when this transition took place vary from the turn-of-the-century to the 1920 s. See Phimister, 'Corners and Company-Mongering', 23.

${ }^{34}$ R. Prain, Copper: The Anatomy of an Industry (London: Mining Journal Books, 1975), 41-42.
} 
In both Northern Rhodesia and Katanga mineral wealth was largely derived from copper. Various observations had indicated the presence of copper mines on the Congo-Zambesi watershed, long before the first European mine exploration companies showed an interest in the area in the 1890s. Cast copper crosses, ingots and bars were traditionally used as currency throughout SouthCentral Africa ${ }^{35}$ Bulk metal and cast copper ornaments had piqued the curiosity not only of the traders who crossed the interior from shore to shore ${ }^{36}$ but also of 'disinterested explorers' and missionaries (including Livingstone, Cameron and Arnot). ${ }^{37}$

It was with the objective of prospecting for every kind of valuable mineral and metalliferous ore that Tanks organised its first mineral-seeking expedition to the concession during the dry season of 1899. Its leader, Grey, believed that mineral deposits would be found between the Kafue River and the Zambesi River, and to the north of the Kafue River. Grey's original plan had been to undertake an expedition lasting between six and nine months that would comprise 'myself and one other white man, twenty donkeys, two or four salted horses [i.e. horses who had recovered from horse-sickness], ten natives (Zulus, Basutos, or the best class of Matabele) who would be armed, a

${ }^{35}$ F.L. Coleman, The Northern Rhodesia Copperbelt, 1899-1962: Technological Development Up To the End of the Central African Federation (Manchester: Manchester University Press, 1971), $172-173$.

${ }^{36}$ See, for instance, R.F. Burton (transl.), The Lands of Cazembe: Lacerda's Journey to Cazembe in 1798 (London: John Murray, 1873).

${ }^{37}$ See, for instance, V.L. Cameron, Across Africa, 2 vols. (London: Isbister \& Co., 1877), i. 134, 319-320, 372; ii. 149, 323-325, 329; E. Baker, The Life and Explorations of Frederick Stanley Arnot (London: Seeley, Service \& Co., 1921), 181; D. Livingstone, Missionary Travels and Researches in South Africa (New York: Harper \& Brothers, 1858), 329. Quotation from J.A. Bancroft, Mining in Northern Rhodesia: A Chronicle of Mineral Exploration and Mining Development (BSAC, 1961), 25. 
light wagon to be left on the South side of the river [Zambesi]'. He asserted that 'the most of the higher country to the North can be explored without encountering fly, thus rendering the possibility of travelling with horses and donkeys possible. ${ }^{38}$

Ultimately the first expedition included five Europeans: Grey, Frederick Crewe (second in command), James Norval Justice (a geologist), Paul MacDonald (a prospector of many years' experience in South Africa), and Mowbray Gore Farquhar (who accompanied the expedition 'for the sake of sport'). It was also reported that 'the party takes with it thirty-five picked natives, Zulus, Fingoes, Mqousas, and Matabele, amongst whom is the well-known scout John Grootboom'. Accompanying the men were 67 donkeys, nine dogs, six oxen, seven horses and two mules. ${ }^{39}$ Grey's expedition set off from Bulawayo for the Congo-Zambesi watershed on 5 April 1899. They travelled along the east side of the Kafue River, with instructions to prospect the Rhodesian side of the Congo border. Roughly 135 miles west of the well-known Nchanga mine and

${ }^{38}$ MU, JRL, TANKS, ZE, 4, George Grey to Robert Williams \& Co., 29 October 1898. Grey based his estimations on information provided by Frederick Crewe, 'an accomplished native linguist' who had been engaged in the labour recruiting business to the north of the Zambesi River (loc. cit.).

${ }^{39}$ G. Grey, 'The Kafue River and Its Headwaters', The Geographical Journal, 18, 1 (July 1901), 62, 76; idem, 'The Tanganyika Concession', The African Review of Mining, Finance and Commerce (hereafter The African Review), XIX, 339 (May 20 1899), 326. Each white member of the expedition had an option on 200 Tanganyika shares for one year at £2. MU, JRL, TANKS, ZE, 3, George Grey to Robert Williams, 2 February 1900. Later, Grey, Farquhar and Justice were given an extension for a further period of one year on account of the South African War. MU, JRL, TANKS, ZE, 3, Robert Williams to ZE, 13 February 1901. Crewe was killed in the fighting at Mafeking and MacDonald died of fever. M. Farquhar, 'The Expedition in 1899', in Some Account of George Grey and His Work in Africa By Men Who Knew Him There (London: Chiswick Press, 1914), 21. 
less than 10 miles south of the border, the party's attention was drawn to the extensive ancient workings of the Kansanshi copper mine where, on 6 September 1899, the expedition pegged claims on behalf of Tanks. ${ }^{40}$ After over six months of silence, Grey returned to Bulawayo and cabled his findings to Williams on 24 November. ${ }^{41}$

Grey's report indicated that the main body of ore was situated in Katanga. However, the initial concession granted to the company did not go beyond the conditions of exploration in Rhodesia. New negotiations over concessionary rights with the Comité Spécial du Katanga (the region's administrative authority), which merged the concessionary rights of the Congo Free State (hereafter CFS) and the Belgian Compagnie du Katanga, were now necessary. According to the new agreement, concluded on 8 December 1900, Tanks was granted exclusive prospecting rights from the CFS within an area of 60,000 square miles adjoining North Western Rhodesia for five years plus an annual subsidy of $£ 10,000$. The Comité Spécial retained its right to 60 per cent of the profits of any opened mines. ${ }^{42}$ This agreement gave Tanks the freedom to prospect the Katanga copper deposits.

\section{Grey's second expedition: establishment of Kansanshi and Kambove mining camps}

After a considerable delay caused by the ongoing South African War, on 15 April 1901 a second, much larger, expedition set out in small parties for the Kansanshi mine, some 850 miles north of

\footnotetext{
${ }^{40}$ Farquhar, 'The Expedition in 1899', 21-24; Justice, 'Prospecting in Northern Rhodesia', 99-104.

${ }^{41}$ Grey, 'The Kafue River', 63. In the press there had been rumours that the expedition had perished. Supplement to The African Review, XXI (November 25 1899), 31.

${ }^{42}$ MU, JRL, TANKS, ZE, 4, Williams to ZE, 25 January 1900; 11 December 1900. See also Bancroft, Mining in Northern Rhodesia, 50; Coleman, The Northern Rhodesia Copperbelt, 7-8.
} 
Bulawayo. Such a large expedition required 200 oxen, the same number of donkeys and a few horses and mules, as well as the many dogs that were brought along for companionship. During the rainy season of 1900-1 a further six spans of Barotse oxen (some 120 animals) had been trained for transport purposes at Kalomo, 100 miles north of the Zambesi River, where they joined the main party. ${ }^{43}$ It was estimated that no fewer than 1,000 porters had been hired by the expedition by the time they reached their base at Kansanshi in October $1901 .^{44}$

A separate section of the expedition was despatched to Abercorn with instructions to locate the township, open a trading store and make preparations for the launch of the S.S. Cecil Rhodes on Lake Tanganyika. The party included four Europeans and 'the requisite native escort'. In total some 200 carriers were employed to transport goods, while donkeys conveyed the whites. The Abercorn section of the expedition left for Katanga on 15 May and proceeded to Lufaku (Lufoi) in the CFS territory; from Lufaku they travelled to Katanga, arriving on 22 June. The Abercorn party became the nucleus of the Katanga section of the expedition and established a permanent camp at Kambove mine,${ }^{45}$ and in this way, the expedition also operated as an unofficial settlement scheme.

In its account of the upcoming expedition Bulawayo Chronicle simply reported that 'The white members of the expedition which leaves here [Bulawayo] are George Grey, Wynn, Jocks, Robinson, Ericson [Eriksson], Boijer, Whitton, Studt, and Dr. Middleton. Messrs Holland and Farrell will start from Abercorn, on Lake Tanganyika, and join the main body of the expedition in

${ }^{43}$ Durham University (hereafter DU), The Barker Research Library (hereafter BRL), Grey Estate Records (hereafter GRE), X/V142, Tanganyika Concessions Ltd. (hereafter TANKS), Reports on the Discoveries Made by Mr. George Grey's Expedition in Northern Rhodesia and Congo Free State, and Reports by J.R. Farrell, Mining Engineer, 5 January 1903, 7.

${ }^{44}$ J.B. Thornhill, Adventures in Africa Under the British, Belgian and Portuguese Flags (London: John Murray, 1915), 129.

${ }^{45}$ DU, BRL, GRE, X/V142, TANKS, 8-9. 
North-Western Rhodesia. ${ }^{46}$ Precious little is known of the expedition's wagon drivers and voorloopers, 'twenty-two Zulus armed with Martini-Henry rifles', personal servants and 'boys', porters or other casual labourers who accompanied the expedition to the north. ${ }^{47}$

We have much more information about the expedition's white members. Franz E. Studt, a German-born mineralogist and recent graduate of the Royal School of Mines in London, was a newcomer in Africa. ${ }^{48}$ Studt's work was used as the basis for the first systematic geological map of the concession. ${ }^{49}$ Dr Richard W. Middleton (1868-1913), from Leeds, had qualified as a medical doctor in 1898 and had been working as a house surgeon at Grey's hospital in Pietermaritzburg prior to joining the expedition. He continued to work as the company's medical doctor, based in Kalomo, until July $1905 .{ }^{50}$ William Whitton, secretary of Bulawayo-based company Williams' Consolidated Buildings, Limited, joined the party in his capacity as an accountant. ${ }^{51}$

46 'Mr. George Grey's Expedition to North-western Rhodesia', Bulawayo Chronicle, March 1901.

${ }^{47}$ See figure 1 of a party that included the Bulawayo section of the expedition.

${ }^{48}$ Hutchinson and Martelli, Robert's People, 120-121.

${ }^{49}$ F.E. Studt, 'Some Notes on the Geology of the Katanga Country and Copper Belt (Read $18^{\text {th }}$ October, 1909)', Transactions of the Geological Society of South Africa, XII (1909), 159-167; idem, 'The Geology of Katanga and Northern Rhodesia: An Outline of the Geology of South Central Africa (Read 30 ${ }^{\text {th }}$ June, 1913)', Transactions of the Geological Society of South Africa, XVI (1913), 44-102.

${ }^{50}$ M. Gelfand, 'Preface', in M. Gelfand, ed., 'Diary of Dr. Richard Watson Middleton, $12^{\text {th }}$ April, 1901, to $18^{\text {th }}$, July, 1902', The Central African Journal of Medicine, Supplement to 9, 5 (May 1963), 6; M. Gelfand, Northern Rhodesia in the Days of Charter: A Medical and Social Study, 1878-1924 (Oxford: Blackwell, 1961), 180-182.

${ }^{51}$ MU, JRL, TANKS, ZE, 4, Wm. Whitton, Secretary, Williams' Consolidated Buildings, Limited, Bulawayo, 7 May 1898. 
The Abercorn section leader was Michael J. Holland, who as the nephew of the former colonial secretary Lord Knutsford had 'just the kind of influence what is wanted. He had been out in Mexico, and had lot of to do with the organizing of the expedition to Kumassi [the Gold Coast], and generally has had the sort of experience that is required for business of this kind. ${ }^{52}$ Durand, a representative of the African Transcontinental Telegraph Company, surveyed their routes. ${ }^{53}$ John R. Farrell, newly appointed chief engineer of Williams' Bulawayo-based mine engineering company, was a graduate of the University of California's Department of Civil Engineering and had worked for 20 years as a mining engineer and mining superintendent in western American mines ${ }^{54}$ Farrell was contracted to assay the most important deposits and to present a report of his findings to Williams. ${ }^{55}$

Thirty-one-year-old Oscar Boijer (1868-1943) and twenty-six-year-old Carl Eriksson (1874-1940), a keen amateur photographer, ${ }^{56}$ were Finnish-born immigrants who joined the

${ }^{52}$ MU, JRL, TANKS, ZE, 4, Williams to ZE, 10 February 1899.

${ }^{53}$ DU, BRL, GRE, X/V142, TANKS, 26.

${ }^{54}$ MU, JRL, TANKS, ZE, 3, Williams to ZE, 20 February 1901, copies of Farrell's testimonials.

55 The official expedition report was handed to Williams in January 1903.

${ }^{56}$ In his travelogue Eriksson provides fascinating details about some of the photographic equipment he used and the difficulties of working in the bush. Like many other amateur photographers, Eriksson seems to have preferred to take photographs that were meaningful to him rather than adopting a more systematic approach. See C.T. Eriksson, Seikkailujeni Afrikka (published in Finnish, hereafter African Diary, all translations by the author) (Jyväskylä: Gummerus, 1932), 70, 72. Despite their historical value, the use of photographs as source material also presents various challenges: in many cases we have no information about the date, place, subjects or even identity of the photographer. Furthermore, it is important to remember that even those images that appear to be candid, may in fact have been posed and selected by a photographer, subject or client (in this 
expedition as prospectors. Both men had only arrived in the mid-1890s, but by 1901 their outlook and experiences had already become largely indistinguishable from those of conventional Rhodesians. Boijer's merits included service in Gifford's Horse during the Ndebele and Shona uprisings of 1896-7 and his prospecting experience in the Gwai River district, while Eriksson had served in the Rhodesia Regiment in the South African War of 1899-1900 and had previously worked at the Bulawayo power plant. $^{57}$

Other than being fit, young bachelors, many of the prospectors had little in common. Charles J. Jocks, 'one of the best type of Dutchmen', was a Transvaaler. Six years later, Jocks became the first prospector to settle permanently with a white woman, in country free from tsetse fly near the Kansanshi mine. ${ }^{58}$ The new company employees differed in terms of race, nationality, profession and class. On the surface, the ethnicity and provenance of the prospectors seemed to matter little. One prospector called John was said to be 'a Portuguese and no one appears to know his proper name, Portuguese John being all that he goes by. He [John] is a good hunter and prospector and a good comrade, which is quite sufficient. ${ }^{59}$ In reality, however, a strict ethnic division was a feature of relations between not only the local population and the class- and raceconscious Europeans, but also various interest groups in the service of the company. ${ }^{60}$

context the company). For a thorough account of the issues involved in analysing colonial photography, see M.W. Daly and J.R. Hogan, Images of Empire: Photographic Sources for the British in Sudan, Sources for African History, III (Leiden: Brill, 2005), 63-64; J.R. Ryan, Picturing Empire: Photography and the Visualization of the British Empire (London: Reaktion Books, 1997).

${ }^{57}$ T. Särkkä, 'Imperialists Without an Empire? Finnish Settlers in Late Nineteenth- and Early Twentieth-Century Rhodesia', Journal of Migration History, 1 (2015), 81-91.

${ }^{58}$ Thornhill, Adventures in Africa, 154, 170.

59 'Diary of Dr. Richard Watson Middleton’, 12, diary entry 3 May 1901.

${ }^{60}$ Särkkä, 'Imperialists Without an Empire?', 91-94. 
Serious technical hazards caused by the rains derailed the original plan for mining development to be undertaken during the rainy season of 1901-2: 'B shaft, in which about eight feet of timbering gave yesterday [8 February 1902] owing to the rain, still continues to collapse; to-night the rest of the timber and the windlass collapsed and are now at the bottom of the shaft [which was 87 feet deep].' 61

On top of these technical troubles, the onset of the rainy season in November saw many men fall ill with high fevers. ${ }^{62}$ Prospecting and labour recruitment were difficult undertakings under these conditions. When Boijer returned to Kansanshi camp on 21 February 1902 after several weeks without contact, Dr Middleton, who had begun to fear the worst, noted: 'Yesterday Boyer [sic] arrived from Kasempa. He looks very pale and ill and somewhat thinner than when we last saw him. He says he has had fever since early in December, off and on the whole time. ${ }^{63}$ In retrospect the expedition was lauded for having surviving the first rainy season without a single death; that is, of course, to say without a single European death. ${ }^{64}$

\footnotetext{
61 'Diary of Dr. Richard Watson Middleton', 55, diary entry, 9 February 1902. See figure 2 of shaft sinking.

${ }^{62}$ Ibid., 55, diary entry, 8 February 1902.

${ }^{63}$ Ibid., 56, diary entry 22 February 1902.

${ }^{64}$ See, for instance, an incident reported by Middleton that apparently led to the death of a mining worker. 'Diary of Dr. Richard Watson Middleton', 61, diary entry 25 April 1902.
} 


\section{Discovery of the Katanga copper deposits}

The discovery of many of the great copper mines of the world was made by prospectors, working on their own or as small companies with the minimum of equipment and the maximum of enterprise, patience and resolution-and often with a great deal of courage. ${ }^{65}$

From June to October 1902 prospectors managed to peg 52 mining areas in Katanga. Commercially the most significant proved to be a native working believed to be 'Karukaruko', which was renamed The Star of the Congo. ${ }^{66}$ The discovery of the Katanga copper deposits was not the plucky event that it may have appeared to have been in retrospect. Prospecting in Katanga was reduced to locating 'ancient workings' rather than using scientific exploration methods to discover previously unknown ore bodies. ${ }^{67}$ Eriksson outlined the strategy his party employed: 'We just asked if the natives knew where we could find makuba [copper] and in exchange for the information we gave the negroes a few metres of cotton-textile [calico] or a cheap blanket, and the deal was done. ${ }^{68}$ After the necessary information was dispensed, pegging was a simple process. First a tree was felled and stripped of bark, after which an aniline pen was used to mark the local name of the

${ }^{65}$ Prain, Copper, 187.

${ }^{66}$ The story of how 'Karukaruko' came to be called the Star of the Congo is told by J.B. Thornhill, who gives Eriksson credit for the find. Thornhill, Adventures in Africa, 165. John Bensley Thornhill was a sometime worker for Tanks who in 1906 applied to be Vice Consul in Katanga District of CFS. The National Archives of the UK, Foreign Office, 369/3/55.

${ }^{67}$ See Zambia's Mining Industry: The First 50 Years (Ndola: Roan Consolidated Mines Limited, 1978), 16.

${ }^{68}$ Hence the retrospective use of the term 'blanket' prospector. See Thornhill, Adventures in Africa, 165. Eriksson, African Diary, 142. See figure 3 of Boijer exchanging calico for information. 
mine or, if there was no mine, the local name of a nearby river or hill, the prospector and the date of the find. (This was done solely for the purpose of informing other Tanks prospectors: concessionary rights kept other mine exploration companies out of the concession.) Then, a discovery beacon was erected, and finally the find was photographed. ${ }^{69}$

During the dry season of 1902, Farrell 'personally examined' Kambove No. 2, Chituru, Likasye, Kamatanda, Msesa No. 2, Kankeru, Karoanso, Kabalela, Kalabe, Karawano, Luushia, Kapushi and Lupota' mines, and presented his detailed expert opinion on these mines to Williams. ${ }^{70}$ However, there are indications that Farrell was more or less incapable of carrying out his inspection work in the concession, which raises questions about the integrity of his report. At some point between November 1901 and May 1902, he became 'mentally affected', according to one of the prospectors, William White. ${ }^{71}$ On Farrell's arrival at the Kansanshi Camp, Doctor Middleton noted his condition.

Yesterday [8 May 1902] Farrell arrived on the mine [Kansanshi], accompanied by Durand (or in his charge would be more correct). Since coming up he has been living quite alone. He cannot speak any Native language and none of his boys speak English, his isolation therefore being complete. The result is that he has completely broken down mentally. He is rather difficult to manage; it is impossible to get him to take sufficient food or necessary medicine. He holds intercourse with the deity, who arranges all his affairs to him, telling him that he must not eat or take medicine. He appears to have been affected this way for some time. ${ }^{72}$

\footnotetext{
${ }^{69}$ Eriksson, African Diary, 146. See figure 4 of native working on Kipushi mine.

${ }^{70}$ DU, BRL, GRE, X/V142, TANKS, 92.

71 'Diary of Dr. Richard Watson Middleton', Appendix C, 'Dr. Middleton by William Robert White'.

${ }^{72}$ Ibid., 63, diary entry 9 May 1902.
} 
A month later, on 18 June, a decision had been taken to transport Farrell to Bulawayo.

Mr. Farrell continues to improve in health and condition, but mentally there is none; in fact, the last day or two he has grown worse, so Mr. Grey has decided to send him down to Bulawayo in my charge, and we are now on the road, having left Kansanshi yesterday noon. White and John are with us and we travel with carriers, Farrell in a machilla [a hammock slung on poles and carried by Africans] ${ }^{73}$

In his report Farrell gives us somewhat more polished version of his time in Northern Rhodesia and Katanga, a reminder that that one man's truth may be another man's fiction.

From the time I crossed the Zambesi, going north, until I re-crossed it in October, the representatives of the British South Africa Company, in North-Eastern Rhodesia, made every effort to facilitate my journey. To their kindness, courtesy and organization I am indebted for much of the comfort and rapidity with which I made a trip unmarred by mishap or accident. ${ }^{74}$

It has been said that 'a general willingness to travel was matched by the emergence of a fresh sense of confidence and professionalism among leading mining sector engineers. ${ }^{75}$ However, whether mining engineers' reports circulated disinterested expert opinion and consequently contributed to more sound investment decisions or whether they produced information which was difficult for non-professionals to evaluate or, worse still, whether they were in some cases

\footnotetext{
${ }^{73}$ Ibid., 63, diary entry 18 June 1902.

${ }^{74}$ DU, BRL, GRE, X/V142, TANKS, 129.

${ }^{75}$ Harvey and Press, 'Overseas Investment and the Professional Advance of British Metal Mining Engineers', 75.
} 
even made by fraudsters has been the subject of some debate among scholars. ${ }^{76}$ The possibility that Farrell did not have particular expertise of Katanga copper deposits or their commercial possibilities illustrates the speculative aspect of mining. Investors were presented with his apparently disinterested expert opinion, the integrity of which was difficult for nonprofessionals to evaluate. ${ }^{77}$ Nevertheless, complicated and confusing expert reports reduced the perception of risk, and thus made investment more likely. ${ }^{78}$

\section{The inception of the wage labour system}

Although mining had undergone a technical revolution in the 1880s and 1890s with the introduction of a range of new industrial processes and engineering techniques, the establishment of modern transport and communication links remained crucially important. During the first years of the 1900s the colonial economy and settler domination were still in their infancy in Northern Rhodesia and Katanga, and in its early operations Tanks was heavily reliant on African manual labour. An operational mining business required considerable infrastructure including roads and railroads, which, like the site installation itself, were largely constructed by African workers wielding axes, picks and shovels. As a consequence, there was a massive, indiscriminate mobilisation of unskilled African labour to fulfil the company's short-term need for labour to undertake shaft sinking, ore

\footnotetext{
${ }^{76}$ See I. Phimister and J. Mouat, 'Mining, Engineers and Risk Management: British Overseas Investment, 1894-1914', South African Historical Journal, 49, 1 (2009), 23-26.

${ }^{77} C f$. Phimister and Mouat, 'Mining, Engineers and Risk Management', 22-26. See also Van Helten, 'Mining, Share Manias and Speculation', 176-177; Harvey and Press, 'Overseas Investment and the Professional Advance of British Metal Mining Engineers', 69.

${ }^{78}$ Mollan, 'Business Failure, Capital Investment and Information’, 230-231, 243.
} 
digging and various auxiliary jobs (such as wood-cutting, clearing vegetation, building bridges, camps and tracks and anti-malarial drainage projects). ${ }^{79}$

It has been believed that when 'the world's mining frontier' passed to the country beyond the Zambesi River, and mines came to be established in increasingly distant areas from markets, it resulted in 'high costs of labour, power, and materials' ${ }^{80}$ This perceived problem of high labour costs did not, however, seem to be a matter of concern for Tanks. Quite the contrary: the low cost of labour was a major asset in mining in Northern Rhodesia and Katanga, as Farrell noted: 'I know of no place where the same amount of mining work could be accomplished for as low a local expense. ${ }^{81}$

It was recruiting an adequate labour force and the consequent need for a steady food supply that caused the most significant problems for early mining development. From the very outset of the development phase, it became apparent that it would be impossible to purchase a steady supply of food locally, at either Kansanshi or Kambove, to sustain all but a small number of local workers. As a result, they adopted the 'posho' system (which prevailed in North Eastern Rhodesia) of supplying local workers with a weekly allowance of calico, with which they could buy their own food. ${ }^{82}$

\footnotetext{
${ }^{79}$ J.-L. Vellut, 'Mining in the Belgian Congo', in D. Birmingham and P.M. Martin, eds, History of Central Africa, 2 (London and New York: Longman, 1983), 136, 138.

${ }^{80}$ C. Schmitz, 'The Rise of Big Business in the World Copper Industry, 1870-1930', The Economic History Review, 39, 3 (August 1986), 402-405.

${ }^{81}$ DU, BRL, GRE/X/V142, TANKS, 98.

${ }^{82}$ DU, BRL, GRE, X/V142, TANKS, 18. See figure 5 of paying Africans in calico. Tanks ordered white and blue calico through Findlay Durham \& Brodie, Merchant Bankers, procuring British manufactured goods and finance for their customers. MU, JRL, TANKS, Tanganyika Concessions (hereafter TC), 29, From Findlay Durham \& Brodie to the Tanganyika Concessions Ltd., 8 September 1905.
} 
According to R.R. Sharp, a Tanks' employee at Kambove, in 1906 the ordinary monthly wage was six to eight yards of calico, which represented about three to four shillings in cash. At one time, workers at Kambove were given two yards of calico on a Saturday afternoon and left to try to buy their own rations for the following week. ${ }^{83}$

This system did not work, however, for those employees whose villages were too far away for food to be regularly brought to them by their own people. As the first mining season (1901-2) advanced, they found it more and more difficult to buy sufficient food to meet their needs. There were no labour regulations in place until 1904, when the principle of raising revenue from the indigenous population through a 'hut tax' was gradually extended to North Western Rhodesia. ${ }^{84}$ For practical, as well as ideological, reasons the wage labour system was preferred over forced labour for most mining and construction work. Sufficient voluntary labour could be secured during most preliminary exploration and development work. ${ }^{85}$ The wish to take part in the money economy in order to buy calico, iron cooking utensils or weapons may have been inducements for those who volunteered. ${ }^{86}$

${ }^{83}$ R.R. Sharp, Early Days in Katanga (Bulawayo: Rhodesian Printers, 1956), 27.

${ }^{84}$ Report of the Commission Appointed to Enquire into the Financial and Economic Position of Northern Rhodesia, 145 (London: His Majesty’s Stationery Office, 1938), 29, 111.

${ }^{85}$ S.E. Katzenellenbogen, 'Labour Recruitment in Central Africa: The Case of Katanga' in The Imperial Impact: Studies in the Economic History of Africa and India, C. Dewey and A.G. Hopkins, eds, (Institute of Commonwealth Studies: University of London, 1978), 271.

${ }^{86}$ D. Jaeger, 'Settlement patterns and rural development: a human geographical study of the Kaonde, Kasempa District, Zambia' (PhD thesis, University of Amsterdam, 1981), 76-78. 
Nevertheless, in the absence of any other options, the only real alternative was to force unwilling Africans to take up mining work. ${ }^{87}$ Ultimately the labour recruiting methods employed depended upon individual labour recruiters: organised labour recruitment did not begin until 1906. Boijer's labour recruiting methods seem to have been notorious. Middleton described how 'A day or two ago a Native came in who reported that at a kraal about 100 miles to the south-east there was a little-man with two police who was very masterful and used his sjambok freely. I expect this is Boyer $[$ sic $] .{ }^{, 88}$ Prospectors were often quick to express harsh criticism or mistreat Africans, whose language and beliefs they did not understand and whose perceived incompetence irritated them. ${ }^{89}$

Besides obvious ethical concerns, labour management also involved economic considerations..$^{90}$ Sound business depended on precise economic planning, reliable calculations and predictable production estimations, all of which remained elusive without direct supervision of the production process and stricter control over the workforce. In Katanga, the early mining industry was concentrated within a region in which villages were widely scattered and rarely had more than

${ }^{87}$ L.H. Gann, A History of Northern Rhodesia: Early Days to 1953 (London: Chatto \& Windus, 1964), 102-103.

88 'Diary of Dr. Richard Watson Middleton', 52, diary entry 22 December 1901.

${ }^{89}$ There are clear indications that Tanks' employees forced the local population into the workforce as porters or regular workers at mines. See, for instance, Eriksson, African Diaries, 164. The dominant contention is that in the Congo mineworkers very rarely took up waged employment entirely freely until the mid-1920s. See O. Lilaka, Naming Colonialism: History and the Collective Memory in the Congo, 1870-1960 (Madison: The University of Michigan Press, 2009). For further on the use of forced labour see A. Roes, 'Towards History of a Mass Violence in the Etat Indepéndant du Congo 1885-1908', South African Historical Journal, 62, 4 (2010) 634-670. ${ }^{90}$ On economic considerations see L.A. Gardner, Taxing Colonial Africa: Political Economy of British Imperialism (Oxford: Oxford University Press, 2012). 
50 inhabitants. ${ }^{91}$ Building on earlier recruitment patterns established by African miners, the vast majority of workers in the Katanga mining industry continued to be of Rhodesian origin. Lamba from North Western Rhodesia had worked as tribute labourers in Katanga's copper mines prior to Yeke dominance of the region. ${ }^{92}$ Recruitment of the Bemba from North Eastern Rhodesia followed from their earlier engagement as porters along Katanga's eastern supply route. ${ }^{93}$ Until about 1924 most UMHK labour was recruited in British administered regions. ${ }^{94}$

The recruitment of workers from farther afield raised a new set of issues: not only the problems of how to secure legal authorisation to recruit and maintain a sustainable level of arrivals (in light of existing local food resources), but also the need to pay greater attention to their workers. Such measures ranged from assessments of physical aptitude and future business needs (in the form of duration of employment contracts) through some codification of working conditions to the very

\footnotetext{
${ }^{91}$ R. Coosemans, 'Occupational Health' in P.G. Janssens, M. Kivits and L. Vuylsteke, eds, Health in Central Africa since 1885: Past, Present and Future, (Brussels: King Baudouin Foundation,
} 1997), 784.

${ }^{92}$ B. Siegel, 'Bomas, Missions, and Mines: The Making of Centres on the Zambian Copperbelt', African Studies Review, 31, 3 (December 1988), 61-84.

${ }^{93}$ The first labour recruitment had its origins in porter system, which sought to provide men to carry goods along transport routes. M.C. Musambachime, 'Labour Migration from Mweru-Luapula 1900-24' in R.H. Palmer, ed, Zambian Land and Labour Studies, II (Lusaka: National Archives of Zambia, 1974), 39-65. In 1901 Tanks transport routes were organised to convey goods and food to the Luapula River and thence to Kambove (from Karonga on Lake Nyasa and later from Blantyre) and to Kansanshi (from Bulawayo and later from the railhead at Kalomo).

${ }^{94}$ Gann, A History of Northern Rhodesia, 107-108; Coosemans, 'Occupational Health', 784. 
practical issues of nourishment, clothing, accommodation and health care. ${ }^{95}$ These concerns came to the fore of Tanks' labour management policy after the First World War: rules governing issues of labour recruitment were redefined as the industry entered into the era of production on a commercial scale.

\section{Experimental smelting at Busanga and Kolwezi}

In the copper industry, vertical integration of mining and smelting capacities was strongly promoted by the move towards larger scale ore deposits, increasingly remote from major markets. The cost of shipping the product to the markets, as well as greater investments in transport infrastructure, encouraged the vertical integration of smelting capacity, since 'this effectively reduced the cost of shipping each unit of metal'.${ }^{96}$ However, the corporate growth theory that in colonial Africa 'the lack of domestic capital formation and the absence of a skilled labour force led to external financing of mineral developments and the employment of foreign miners and managerial personnel' ${ }^{97}$ does not seem to fit seamlessly with the case of Tanks. Ultimately, local metallurgical knowledge was an important asset that ensured Tanks' early success in experimental smelting. N. Samwell, mining engineer, who inspected the company's tin-bearing properties at Busanga in 1904 paid attention to local specialised metallurgical knowledge about smelting: '[...] the Natives on the spot are to be

${ }^{95}$ Coosemans, 'Occupational Health', 781-782. Dr Pearson and Dr Mouchet were the first UMHK medical officers to contemplate these concerns systematically. See A. Pearson and R. Mouchet, The Practical Hygiene of Native Compounds in Tropical Africa: Being Notes from the Experience of the First Eighteen Years of European Work in the Katanga (London: Ballière, Tindall and Co., 1923). ${ }^{96}$ Schmitz, 'The Rise of Big Business', 405-407.

${ }^{97}$ Van Helten, 'Mining, Share Manias and Speculation', 160. 
recommended - and as they have been smelting both Copper and Iron for generations past for their own requirements, there would be no difficulty in making use of their labour for tin smelting operations.' 98

Eriksson, the 'pioneer smelter man', as he was nostalgically known, ${ }^{99}$ carried out experimental smelting of tin ore at Busanga during the rainy season of 1904-1905. The first tin bars were reported to the company accountant based at Kambove in January $1905 .{ }^{100}$ Eriksson had carefully studied the metallurgical and charcoal manufacture processes used by local expert families or guilds specialised in smelting processes, and managed to build an experimental reverberatory furnace for tin smelting at Busanga. ${ }^{101}$ Possibly on the basis of a proposal put forward by Samwell (who had experience in tin smelting in New South Wales, Heberton, Queensland, and Malay Peninsula), the furnace at Busanga was later modified according to the model used by Chinese tin smelters in the Malay Peninsula. This type of furnace was built on the spot from fire brick, small iron castings and small portable blowers. ${ }^{102}$

Early in 1903, Williams had approached the railway contractors George Pauling \& Co. with a proposal to construct a railway from Lobito Bay in Portuguese West Africa to the copper mines. When it proved impossible to raise the necessary funds, alternative arrangements were made to extend the line from Bulawayo in a north-western direction towards Victoria Falls via Wankie. ${ }^{103}$

\footnotetext{
${ }^{98}$ MU, JRL, TANKS, TC, 29, From N. Samwell to Robert Williams, 1 July 1904.

99 ‘Charles Eriksson - Pioneer smelter man', Horizon, I (November, 1959), 24-26.

${ }^{100}$ MU, JRL, TANKS, TC, 146, Kambove Accountant, Busanga Tin Smelting Accounts, January to March 1905.

${ }^{101}$ Eriksson, African Diary, 206-210; Sharp, Early Days in Katanga, 9.

${ }^{102}$ MU, JRL, TANKS, TC, 29, From N. Samwell to Robert Williams, 1 July 1904.

${ }^{103}$ MU, JRL, TANKS, TC, 29, From the Tanganyika Concessions to Messrs. Emile Erlanger \& Co., 6 October 1903. On the financial alliance between the BSAC, the railway contractors George
} 
The extension of the railway north of Victoria Falls to Kalomo was completed in 1905, and Broken Hill was reached the following year. ${ }^{104}$ On 16 January 1906 two small water-jacket furnaces were transported from the railhead at Kalomo to Kolwezi using a great deal of African labour and at the cost five carriers' lives. ${ }^{105}$ Being so small, with a capacity of only $900 \mathrm{lbs}$, the water-jacket furnaces caused such a lot of work and trouble that their use was soon discontinued. Locally constructed furnaces, using large bricks made from powdered ant-heap proved much more successful. ${ }^{106}$

The first European-produced copper at Kolwezi was reported to have been smelted on 7 July $1905,{ }^{107}$ some six years before the smelter, capable of producing copper on a commercial scale, came into operation at Lubumbashi. ${ }^{108}$ By 1910 the railway had extended as far as Elisabethville, the administrative capital of Katanga, built adjacent to the Star of the Congo Mine. This rendered

Pauling \& Co and the merchant bankers the House of d'Erlanger see C. Andersen, British Engineers and Africa, 1875-1914 (London: Pickering \& Chatto, 2011), 76.

${ }^{104}$ D. Buchan, ed, The Chronicles of a Contractor: Being the Autobiography of the Late George Pauling (London: Constable, 1926), 204, 206, 212-214.

${ }^{105}$ Eriksson, African Diary, 242-252. The furnaces had been made in Kimberley for the company as small-scale copies of the full-size water-jacket furnaces that were used by the large coppersmelting outfits in America.

106 Thornhill, Adventures in Africa, 86-87.

107 'Charles Eriksson - Pioneer smelter man', 26.

${ }^{108}$ The first copper in Katanga was brought to the stage of commercial production at Lubumbashi Smelting Works on 16 September 1911. For further information see 'The Development in Central Africa. A Tour to the Great Copper Belt of Katanga, the Mines, Railways, and Work of the Tanganyika Concessions, Ltd. VI. The Smelting Works at Lubumbashi', The Times (16 November 1911), 19. 
possible an integrated rail transport system: trains could haul copper from Katanga to Beira in Mozambique and return with coal and coke from the Wankie area in Southern Rhodesia. ${ }^{109}$

\section{Winners and losers of early mining economy}

As it transpired, the Katanga copper mine deposits were not isolated occurrences but part of a vast geological formation, the like of which was not known outside Africa. Nevertheless, in 1906 Tanks' future seemed to be under threat due to a fall in copper prices and the end of its five-year agreement with the Comité Spécial over concession rights in Katanga. The founding period of the company came to an end on 28 October 1906, when Union Minière du Haut Katanga (hereafter UMHK) was formed to exploit mineral deposits pegged for Tanks. ${ }^{110}$

The Katanga interests proved to be 'something of a lottery ticket' ${ }^{111}$ for Tanks shareholders. The increase in their value was also reflected positively in the bonuses of the early white employees of the company, many of whom were obvious winners of early mining economy. Prospectors received $£ 20$ per month and five per cent of everything they managed to peg. ${ }^{112}$ Later arrivals were not always so lucky. Rumours of mineral discoveries attracted so many 'stiffs' (white men

${ }^{109}$ Gann, A History of Northern Rhodesia, 117;idem, The Birth of a Plural Society, 127; Bancroft, Mining in Northern Rhodesia, 45-53.

${ }^{110}$ For further information, see Union Minière du Haut Katanga 1906-1956, 9-16.

111 'The Tanganyika Concessions, Limited, in the Congo', The African Review, XXIX, 474 (21

December 1901), 459.

${ }^{112}$ In 1906 this was the subject of some dispute between the company management and Eriksson, who resigned from his position with Tanks on 31 May. See MU, JRL, TANKS, TC, 146, Kambove Accountant, Eric Douglas, Kambove, 31 July 1906. 
inadequately equipped and depended on African foods, who nevertheless took to wandering across the area in search of work $)^{113}$ that Grey felt compelled to issue a warning in The Livingstone Mail that there was no chance of securing mining employment with Tanks. ${ }^{114}$

The opening of the Ruwe Hill gold mine in late 1903 and further prospects of locating payable gold-bearing deposits were discussed enthusiastically at the company's annual general meeting. ${ }^{115}$ The speculation that surrounded the possibility of a payable gold-bearing reef was at least as important to the company's economic viability as were the very rich copper deposits. Only two mines, The Star of the Congo (Lubumbashi) and Kambove, were operating at the outbreak of the First World War. The Busanga tin mine had ceased operations in 1909, although it was reopened by UMHK after the First World War; ${ }^{116}$ the Kansanshi copper mine was only operational for a period during the war, but it too was later reopened. ${ }^{117}$ Ultimately, the munitions industry's ongoing demand for non-ferrous metals during the war and the resulting strategic importance of copper served to boost mechanisation in the 1920s. ${ }^{118}$ By this time the period of experimental

113 Thornhill, Adventures in Africa, 235.

${ }^{114}$ G. Grey, 'Notice', The Livingstone Mail, I, 21 (18 August 1906).

115 'Big Proposition', The African Review, XXXVIII, 582 (January 16 1904), 149.

116 'Background to a Punctuated History' in M.J. de Wit, F. Guillocheau and M.C.J. de Wit, eds, Geology and Resource Potential of the Congo Basin (Springer: Heidelberg, 2015), xxiv.

${ }^{117}$ R.L. Prain, 'The Growth of the Copperbelt of Northern Rhodesia', The Financial Times, 1 June 1953, 14. Today, Kansanshi is operated by First Quantum Minerals Ltd., which other properties are located in Spain, Mauritania, Australia, Finland, Turkey, Panama, Peru and Argentina.

${ }^{118}$ From the inception of production at Lubumbashi in 1911 to the height of the trench war in 1916 the average London Metal Exchange price of copper rose over 50 per cent (from $£ 77.21$ to $£ 136.85$ per imperial tonne). See C.J. Schmitz, World Non-Ferrous Metal Production and Prices, 1700- 
mining and smelting was over, and the industry had entered the era of production of a commercial scale.

\section{Conclusions}

This article has discussed the operation of the colonising processes of the London-based mining and mine exploration company Tanganyika Concessions Limited. It has sought to analyse how Tanks' colonising processes took place, why they were considered desirable by various interest groups, and the impact that these processes had on physical and human environments in parts of North Western Rhodesia and Katanga. In more general terms, the article has sought to make a case for analysing City finance's impact upon empire-building in colonial Southern Africa.

Of the numerous registered companies involved in mining and mine exploration in colonial Southern Africa, Tanks was one of the very few successes. It was responsible for the far-reaching effort to set up a European mining industry in the mineral-rich region that later became popularly and loosely known as the Copperbelt. There is another aspect which makes Tanks a relevant case study: the wide range of available materials - a prospectus, company records as well as personal material (diaries, travelogues and photographs) of the company's many workers in the field - offer a fuller picture of the inception of European mining and mine exploration in Northern Rhodesia and Katanga than is available elsewhere.

Mining has been analysed by both economic historians and researchers of colonialism, but the extent to which British capital ultimately revolutionised economies and societies in colonial Southern Africa continues to be a highly debatable subject. Despite extensive existing

1976 (London: Frank Cass, 1979), 271. See also J.S. Ball, 'The German Octopus: The British Metal Corporation and the Next War, 1914-1939', Enterprise \& Society, 5, 3 (September 2004), 452. 
historiography, very little is known of individual mining companies' operations on the ground before 1914. Tanks' mining and mine exploration operations have been approached from the perspective of powerful capitalists and financiers (Robert Williams, Cecil Rhodes and others). However, a very much more complex story emerges when written and visual materials produced by the company's employees on the ground are analysed. Descriptions related to the discovery of the Katanga copper deposits, the inception of the wage labour system and the operations related to the experimental smelting can differ significantly depending on whether one consults the prospectus, company records, diaries or visual material. The heterogeneous sources can also complement each other, allowing a fuller story to be told and a sounder case to be made. Entries from Middleton's and Eriksson's diaries provide different impressions of the discoveries than the reports submitted by Grey and Farrell. Depictions of Kansanshi mining camp during the first mining season (including mining and employed Africans being paid in calico) help us to appreciate how Tanks' colonising processes slowly but irreversibly started to mould physical and human environments for the purposes of colonial economy. Such visual representations show us scenes, processes and people otherwise known to us, if at all, only through the written word.

Prior to 1906, before the construction of roads, railroads and telegraph lines, Tanks' mining and mine exploring operations were run by local management with the help of engineering firms, suppliers and service sector agencies. With technical and production matters left in the hands of local management, the company's directors sought to attract the attention of investors by circulating the favourable report on discoveries. Speculation and company promotion was considered an important aspect of the mining business; before 1906 most of the company's assets were diverted into the construction of the requisite infrastructure; at the same time the mines themselves were starved of working capital. The exploitation of mineral wealth was heavily dependent on a cheap supply of African labour. Tanks' early mining industry was concentrated in an area with a relatively small African population: this meant that while there was little pressure upon land, conversely there 
was only a relatively small pool of labour from which to recruit. White management employees worked in relative solitude, in remote lands, amidst alien peoples, languages and habits; they had very little contact with company-level management and often had to rely on their own initiative. This situation, coupled with the absence of labour regulations and conventional bourgeois taboos on race, gender and class, left the local population vulnerable to abuse at a time when colonial rule was still in its infancy.

When production became a more pressing concern than company promotion, efforts to verify the economic viability of ore lodes intensified. Instead of just being a 'brass nameplate' company in the City, Tanks became increasingly grounded in specific localities and began to transform existing physical and human environments. It set up mining camps, recruited workers (and sometimes apparently used forced labour), created a system of paid jobs, sank shafts, carried out experimental smelting work, cleared vegetation and built roads and railroads. In other words, the company did everything that was considered requisite for setting up a mining business. Changes caused to the social structure brought new challenges alongside prosperity, especially for the company management, who were also major shareholders. The operation of early mining economy led directly to large-scale migration of African labourers and the creation of mining communities. Mining development also had a political dimension: most notably the almost invariable restriction of Africans to the lower ranks, thus reinforcing the authority of white workers over African employees. ${ }^{119}$ That race, ethnicity, profession and class operated as lines of demarcation and

${ }^{119}$ On these concerns see, for instance, C. Harvey and J. Press, 'Issues in the History of Mining and Metallurgy', Business History, XXXII (July 1990), 4-5; B. Fetter, The Creation of Elisabethville, 1910-1940 (Stanford University: Hoover Institution Press, 1976); C. Perrings, Black Mineworkers in Central Africa: Industrial Strategies and the Evolution of an African Proletariat in the Copperbelt, 1911-41 (London: Heinemann, 1979); Katzenellenbogen, 'Labour Recruitment in Central Africa', 270-279. 
division is evident from relations between various interest groups in the service of the company.

The pervasiveness of these hierarchies (both at the time and beyond) can be perhaps most obviously seen in the overemphasis placed on the role of powerful capitalists at the expense of workers making their own history. 